\title{
Conditions at the Central Nervous System Level Due to the Use of Psychopharm to Increase Academic Performance
}

\author{
Juan Farak Gómez \\ Researcher Medical Research Group (GINUMED), Universitary Corporation Rafael Nuñez, Colombia
}

\section{EDITORIAL}

A high increase has been observed in the last decades in the tendency of some young university students towards the consumption of some psychotropic drugs in order to increase their academic performance; which are substances that can significantly alter the functions of the central nervous system (CNS); specifically, brain and spinal cord [1].

The term psychoactive drug is applied to compounds that modify both psychic functions and mental states and are used primarily for the treatment of mental disorders, that is, they are compounds that induce neurological, psychological and physiological effects, due to their ability to modify the action of neurotransmitters in the brain and include both so-called psychoactive substances and psychoactive drugs.

The action of psychotropic drugs is fundamentally symptomatic and, in some cases, prophylactic to avoid relapses.Its proper handling can facilitate the recovery of the patient, but their misuse or abuse can lead to the appearance of undesirable effects with a significant decrease in the aptitudes and abilities that will negatively affect their quality of life [2].

From several studies carried out, it has been described that among its possible mechanisms of action we find alpha- 1 adrenergic stimulation followed by interactions in the dopaminergic systems and the participation of serotonergic mechanisms such as GABA, however, it should be noted that the theory of The one with greater certainty is the one that speaks of the agonism of the central alpha adrenergic receptors, where it has been detected that the stimulation induced by modafinil, which is one of the most widely used psychotropic drugs, seems to be located in the hippocampus subregions, the centrolateral nucleus thalamus and the central nucleus of the amygdala, as indicated by some studies in animals in which modafinil increases glutaminergic transmission in the thalamus and hippocampus [3]. The most frequent adverse reactions found from the ingestion of these substances are all related to the central nervous system, which includes symptoms such as: headaches, nausea, vomiting, nervousness, and insomnia. These occur in more than $5 \%$ of patients, other side effects related to the central nervous system are amnesia, ataxia, confusion, dizziness, oro-facial dyskinesia, emotional fragility, hypertonia, paresthesias and tremors, which affect a little more than $1 \%$ of the cases [4].

According to epidemiological studies, the figure of 500,000 annual deaths attributed to the effect on the CNS of these drugs has been reached in Europe and the United States, which represents one of the main causes of death, within this figure it is worth mentioning that psychotropic drugs have caused problems such as anxiety and depression in more than $50 \%$ of the patients, $57 \%$ also presenting a decrease in libido, where $1.7 \%$ correspond to university students who consume substances such as ritalin (methylphenidate), cidrin (methamphetamine) and fenproporex (phenylisopropylamine) [5].

In conclusion, it could be said that psychotropic drugs are substances that in a certain way help improve academic performance, but their misuse leads to various adverse reactions with serious consequences for those who consume them, which will end up affecting life academic and the academic performance of the students.

Given these effects, the abrupt disuse of these drugs could also have consequences contrary to the effect of the drug. This leads us to say that psychotropic drugs to a large extent, if they are not used with medical indications, can lead to such alterations, for which the students should be guided and warned about the use of these substances.

\begin{tabular}{c|l} 
Quick Response Code: & $\begin{array}{l}\text { Address for correspondence: Juan Farak Gómez, Researcher Medical Research } \\
\text { Group (GINUMED), Universitary Corporation Rafael Nuñez, Colombia }\end{array}$ \\
\cline { 2 - 3 } & $\begin{array}{l}\text { Received: March 02, } 2021 \quad \text { Published: March 05, 2021 } \\
\text { How to cite this article: Juan FG. Conditions at the Central Nervous System Level Due to the } \\
\text { Use of Psychopharm to Increase Academic Performance. 2021- 3(2) OAJBS.ID.000261. DOI: } \\
\text { 10.38125/OAJBS.000261 }\end{array}$ \\
\hline
\end{tabular}




\section{REFERENCES}

1. Rodriguez HJA (2018) Rendimiento Académico Medición, Apreciación, Evaluación?, Factores influyentes en la definición del Rendimiento Académico. Paradigmas, 2(1): 109-117.

2. Zorzetto D (2010) Psicofármacos: consulta rápida. Revista Brasileira de Psiquiatria 32(4): 471.

3. Rajkumar RP (2015) A patient-centered model of the action of psychotropic drugs. Personalized Medicine Universe 4: 46-53.
4. Reseña: Psicofármacos que matan y denegación organizada (2018) Psicología, Conocimiento y Sociedad 8(2) 1-4.

5. Vercellino M, Philippi R (2020) Sexualidad, Depresión y Antidepresivos. ¿Cómo enfrentar este dilema? Revisión comprensiva del uso de psicofármacos en Trastorno Depresivo Mayor y Sexualidad. Revista chilena de neuro-psiquiatría 58(4): 400-412. 